\title{
Narrative Analysis of Stream of Consciousness in A Dill Pickle
}

\author{
LIU Xi, CUI Guo-yue \\ Changchun University, Changchun, China
}

\begin{abstract}
Katherine Mansfield (1888-1923) was a modernist writer of short stories who was born in New Zealand. She was a creative author because she broke the traditional writing way. What attracted people's attention were the feminist thoughts and the stream of consciousness as a writing skill in her shorts stories. A Dill Pickle, published in 1917, was a such representative sample. It narrated the meeting between Vera and the man after six-year separation including the memories between them, the journey of the man. This paper aims to analyze the writing skill of stream of consciousness from the perspectives of interior monologue, direct utterance, and time montage in the plot in A Dill Pickle.
\end{abstract}

Keywords: stream of consciousness, interior monologue, direct utterance, time montage

\section{Introduction}

Katherine Mansfield was one of the innovative fictionist and outstanding modernist in English literary circle. She had a really ephemeral life but she bent herself to writing and kept her eyes on the intricate and delicate relationship between men and women in her whole life. There were many famous short stories in the English language written by Mansfield, mentionable for the craftsmanship, the creation of moods, and the revelation of character. It was Katherine Mansfield who gave the writing world great influence that revolutionized the English short stories which marked the maturity of British literature so that she was always compared to Dickers and Chekhov. The most conspicuous traits in her literary works were feminism and stream of consciousness. Her wiring skills and achievements arrived at the peak with Bliss (1920) and The Garden Party (1922). In A Dill Pickle, she broke the traditional form of fiction and adopted stream of consciousness to recount the story about Vera and the man. She used authorial voice to make readers comprehend the whole story and curtail the distance between the author and the readers. She gave an account of the meeting between Vera and the man after six-year separation. When they reminisced, the readers begin to know what happened that finally led to the end of their relationship. Katherine Mansfield gave expression of Vera's hesitation, regret, and determination. The paper aims to introduce writing skill of the stream of consciousness reflected in $A$ Dill Pickle from the perspective of interior monologue, direct utterance, and time montage. Then, it will show how the author exerts the skill to achieve the success of the story.

LIU Xi, lecturer, M.A., School of Foreign Languages, Changchun University.

CUI Guo-yue, undergraduate, School of Foreign Languages, Changchun University. 


\section{Interior Monologue by Vera}

Monologue is the main narrative device in the fictions with the skill of stream-of-consciousness and it can be divided into three categories, including direct and indirect inner monologue and drama monologue. The direct inner thoughts reveal inner monologue that involves any level of consciousness. The indirect heart monologue involves a sub-consciousness. And it is also authorial voice that can make the story more integrated. "Authorial voice could be used for indicating heterodiegetic and had potential recitative" (Lanser, 2003, p. 18). In A Dill Pickle, interior monologue is widely used to explore the psychological activities of the protagonist - Vera - so as to enrich her inner world and promote the development of the plot as well.

In the whole story, Vera did not say much but thought and felt a lot with the pattern of interior monologue. As Vera was the protagonist of the story, almost all her interior monologue that promoted the story was about her memories concerning the past, her consideration about the man's present performance and the ending of the story. The story began and ended in the way how Vera revealed her inner monologue. In a sense, this way may make Vera and readers become combinative and even lead readers to support Vera's choice.

In A Dill Pickle, interior monologue by Vera is widely used. After she learned that the man made a journey in Russia by himself, "She felt the strong beast that had slumbered so long within her bosom stir, stretch itself, yawn, prick up its ears, and suddenly bound to its feet..." (YANG, 2012a, p. 60). It was her long-standing wish to travel to all these distant and mysterious places. The dream had been hidden deep in her heart for a long time because it was unfeasible for her to achieve. After leaving the man, Vera became down and out and even sold her piano which was her interest. As to her, being alive was an unfavorable thing and the piano was the more extravagant affair. So when the man mentioned the Black Sea, “...black as velvet, and rippling against the banks in silent, velvet waves. She saw the little group on the grass, their faces and hands white in the moonlight" (YANG, 2012a, p. 61). Vera began to image that she was there and enjoy the landscape. It seemed a little laughable, however, it must be ordinary for Vera who desired to do but did not have the ability. There was not a surprise in store to readers that all of them made Vera oppugn her and she began to show a little repentance for leaving the man. "Ah, God! What had she done! How had she dared to throw away her happiness like this! This was the only man who had ever understood her" (YANG, 2012a, p. 62). Vera took into account that being the girlfriend of the man again might be an ideal option for her because now he was capable and wealthy enough to provide her a dreamy life. She might think that the man was the only one that could help her to carry out her dream. As for all of the feelings, however, Vera told nothing directly to the man but smiled gently at him all the time. With the skill of inner monologue, Vera was covered with a veil of mystery so that she became more impressive and attractive to both the man and the readers. As a matter of fact, facing the man, Vera tried to preserve her scanty dignity and elegance though she was down and out. When the man made a parade of his journey, Vera was always a good listener. Though she often plunged into silence, her interior monologue made readers understand and support her better.

Interior monologue served as a bridge to connect the thought of Vera and the understanding of the readers. With the device of interior monologue, we can discover Vera's fear, hesitation, and motivation reflected in her silence. In this sense, we will show sympathy for Vera involuntarily and comprehend the reason why she left the man six years ago and left him again now. Moreover, we will be anxious about her untoward life and care about 
her unpredictable future. Finally, Vera changed her attitudes towards the man, which was a difficult process, so that she showed her ability of being persevering, self-governed, and backboned.

It is straightforward and answerable that interior monologue is an important component of the stream of consciousness, which makes the story become picturesque and amusing so as to make the readers be personally on the scene. Through the interior monologue of Vera, it assumes a new method to show the story and the truth because it gives a particular description of the past in a unique way. Beyond all question, it was really an intelligent and adventurous decision to use the interior monologue to write the story.

\section{Direct Utterance by the Man}

Direct utterance is also a major part of the stream of consciousness. Writers always used this way to show the feelings of the character directly. "What the dramatis personae say is an intermediary between the progress of story and the readers" (Phelan, 2003, p. 39). Beyond all doubt, direct utterance is a result that the consciousness chooses. It makes the readers comprehend the meaning, feature, and disposition of the character and it makes the essay become more visualized and vivid as well. It can make the readers feel that they are at the locale as well. It is a traditional fashion, but not only by tradition.

In A Dill Pickle, direct utterance devices about the man are widely and repeatedly used as an important method to propel the story which is based on the ideology of Vera and the insecure connection of the memory. The interior monologue of Vera could not be separated from the direct utterance device by the man. On the one hand, the author adopted the direct utterance device largely for the sake of providing writing materials for Vera, while, on the other hand, the direct utterance device may be chosen by Vera deliberately. Thus, it could be viewed as the consciousness of Vera.

After six years, the man failed to recognize Vera at the first sight of her. Later, when they began to talk, however, the man talked much more than Vera. The man was so eager to make him understood by Vera that he was even ready to chime in with his opinion all the time. When Vera complained about the awful weather, he interrupted her "Excuse me, please bring some coffee and cream" (YANG, 2012a, p. 59). The man was always interrupting her as what he had done in the past. He exhausted himself by talking as if Vera was like a lamentable woman who had no right to say something but listening to him. Then, the man talked a lot about his journey in Russia and showed a little interest in Vera's life. It was not a light and gay conversation, but was an ostentatious display of wealth. Vera might be a little compunctious for the break-up before, but now she showed the aversion to the man. Finally, at the final ending of the story, the man gave an appraisement about Vera, "It simple was that we were such egoists, so self-engrossed, so wrapped up in ourselves that we hadn't a corner in our heart for anybody else" (YANG, 2012a, p. 63). He said so excitedly as if he was the only one who could understand Vera so well. He never expected that Vera left him confirmedly after hearing what he said. Under the distressful circumstance of poverty and sickness, Vera could choose to leave the man that was really difficult but inevitable.

Considering what the man said, it seemed that the man was in an even more dominant position in the story, but as a matter of fact, the man was just a connecting part. From the man's direct utterance, both the man's situation and Vera's present life were well revealed so that the readers could understand the story better. It seemed that the man was given more chances to talk; nevertheless, the more he talked, the more aversion the readers would take to him. To a certain degree, the man's direct utterance was partly a reflection of Vera's 
consciousness. In the meanwhile, what the man uttered was a direct and real picture of him, being cold-hearted, hypocritical, arrogant, and self-engrossed. All of the man's utterance made Vera more impressive to readers. Undoubtedly, the man's role always served as a contrast to Vera. Thus, readers could have a trenchant argument to understand what Vera did and how outrageous the man was.

It seemed that the direct utterance device was not a vantage for the man and the man lost all precious things except money. Though he had an affluent life, he was the really pathetic and needy person under the consciousness of the author. Though the direct utterance device was viewed as a traditional way to write stories, as for A Dill Pickle, it was widely used by a choice of Vera's consciousness. It made the story a successful model for the later writing.

\section{Time Montage in the Plot}

The origination of montage was related to film production. With this skill, films could be cut off and be joined together by chemical reagent. Then people began to shoot from different perspectives, and in different positions and distance. With the appearance of sound films in 1927, montage was used more nimbly. Nowadays, it is comprehensively used in films, painting, advertisements and writing.

Montage refers to film editing. In films, it is the modality and measure of constituting. In fictions, writers use montage to construct different space frames and make the story stereo. As for stream of consciousness, montage consists of time montage and space montage. "Time montage means the protagonist can think about past, present and future things at the same time. Space montage means the fiction can show different spaces at the same time" (Friedman, 1955, p. 58). Time montage allows for the readers to grasp imagery more vividly and gives more life to it. It speeds up the story by collecting the main events of a time line as well and it was a vivid way of summarization.

In A Dill Pickle, Mansfield used time montage in plot to express Vera's consciousness. In the story, When she talked with the man, Vera traced her memories back to the past time, such as the particular afternoon and the Christmas day. In the particular afternoon, "You still say the same things and there is another thing about you that is not changed at all-your beautiful voice" (YANG, 2012a, p. 59). Though the man said that Vera taught him the name of the flowers, he could remember nothing about them. After hearing what the man said, Vera tried to recollect things and drew herself in them. However, as for Vera, she could remember how the man conducted liked a madman and how the other people jested at him. It was an extraordinarily dissimilar feeling between Vera and the man. On the Christmas day,

How I remember one night, the night that I brought you the little Christmas tree, telling you all about my childhood. And of how I ran away and lived under a cart in our yard for two days without being discovered. (YANG, 2012a, p. 61)

It seemed that the man had really done many things for Vera and had loved her deeply. When Vera referred to the dog, however, the man could not remember anything. The fact was that the man did not really care or love Vera at all. The feelings about the past and the present days made Vera recognize the truth and abandoned the ludicrous illusion about the man. With the skill of time montage, readers could compare the past with the present so as to help readers understand the relationship between Vera and the man. In this sense, it was an adaptive way to recount the tale. With the skill of time montage, the readers could comprehend what had happened six years 
ago without mixing some important details in the plot.

Time montage breaks through traditional limited time and furnish short story with a new pattern to create a delicate plot so that readers can follow protagonist's consciousness to survey the whole story. It seems that the rule is not easily perceived, but it is an innovative way to help readers to comprehend the significance of the story and the protagonist would be endowed with life and emotion.

\section{Conclusion}

From what has been mentioned above, we can draw a conclusion that Mansfield used the stream of consciousness to represent the whole fiction in A Dill Pickle. The three parts of it consist of interior monologue by Vera, direct utterance by the man and time montage in plot that enhances the value of this short story. Vera's consciousness was the soul of the story. All the other details aimed at ensuring the evolution of the tale and readers' attitudes, viewpoints, and choices could be consistent with Vera. Mansfield characterized Vera into an reminiscent, emotional, sensitive, and courageous woman with feminist thoughts. The stream of consciousness in A Dill Pickle was a successful attempt that exerted an influence on other authors. There was no doubt that using the stream of consciousness was a prosperous way to make an exceptional story, thus, it made Mansfield well-known throughout the whole world. When modern readers are bent to A Dill Pickle now, there is still a good deal of enlightenment that they can acquire from it.

\section{References}

Booth, W. (1961). The rhetoric of fiction. Chicago: University of Chicago Press.

CUI, S. Y. (2002). Post modernism and European and American literature. Beijing: China Social Science Press.

Friedman, M. (1955). Stream of consciousness: A study in literary method. New Haven: Yale University Press.

Lanser, S. S. (1981). The narrative act: Point of view in prose fiction. New Jersey: Princeton University Press.

Lanser, S. S. (2003). Constitution of fiction. Beijing: Peking University press.

Mansfield, K. (1962). Bliss and other stories: Dill Pickle. London: Penguin Books.

Phelan, J. (2003). Native as rhetoric. Beijing: Peking University Press.

Wilfred, L. G. (2004). A handbook of critical approaches to literature. Beijing: Foreign Language Teaching and Research Press.

YANG, L. M. (2012a). Contemporary college English. Beijing: Foreign Language Teaching and Research Press.

YANG, L. M. (2012b). Teachers' book of contemporary college English. Beijing: Foreign Language Teaching and Research Press. 